\title{
Asymptomatic Inflammatory Prostatitis
}

National Cancer Institute

\section{Source}

National Cancer Institute. Asymptomatic Inflammatory Prostatitis. NCI Thesaurus. Code C94410.

Inflammation of the prostate gland that is not associated with any symptoms. It is characterized by the presence of inflammatory cells in the prostatic fluid. 